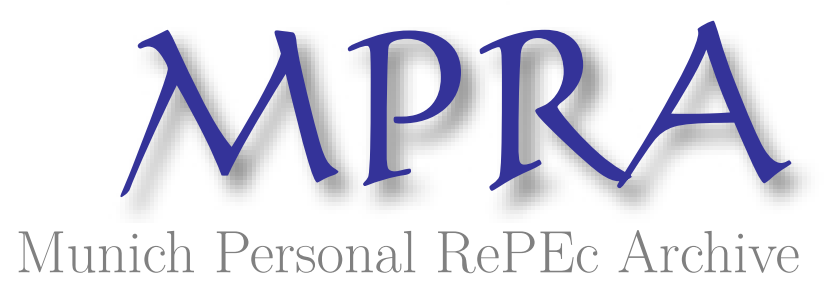

\title{
Understanding and evaluating the "missing" governance pillar of sustainability - the case of the Bulgarian agriculture
}

Bachev, Hrabrin

Institute of Agricultural Economics, Sofia

February 2021

Online at https://mpra.ub.uni-muenchen.de/106310/

MPRA Paper No. 106310, posted 03 Mar 2021 14:21 UTC 


\title{
Understanding and Evaluating the "Missing" Governance Pillar of Sustainability - the Case of Bulgarian Agriculture
}

\author{
Hrabrin Bachev ${ }^{1}$
}

The importance of "good governance" for achieving agrarian sustainability has been increasingly studied in the last two decades. What has been a recent development is the inclusion of governance into (agrarian) sustainability as a new "fourth" pillar. Still there is no consensus on: what is governance sustainability; how to measure governance sustainability; how to integrate governance into the overall sustainability; what are critical factors determining sustainability levels, etc. The goal of this article is to present a holistic framework for defining and assessing the governance sustainability in agriculture, and assess the level of governance sustainability of Bulgarian agriculture at national, sub-sectoral, regional, ecosystem, and farming organization levels.

The study has demonstrated that it is possible and important to assess the "missing" Governance Pillar of agrarian sustainability. Governance sustainability of Bulgarian agriculture is at a good but close to the inferior level. There is a considerable variation in the level of governance sustainability and application of the principles for good governance in different subsectors, agro-ecosystems, administrative regions, and types of farming organizations. At current stage, most critical for improving the governance sustainability are progressive changes in: farmers' participation in decision-making, agrarian administration efficiency, administrative services digitalization, possibility for lands extension, management board external control, level of informal system efficiency, subsidies in income, extent of CAP implementation, acceptability of legal payments, and land concentration.

Suggested and other similar frameworks have to be further discussed, tested, improved and adapted to the specific conditions of agricultural systems and the needs of decision-makers. Accuracy has to be improved through the inclusion of appropriate indicators, improvement of precision of the information, increasing representation of surveyed farms, and experimenting with diverse types of agro-systems.

Keywords: governance, sustainability, assessment, agro-systems, Bulgaria JEL codes: Q12, Q15, Q18, Q56

1 Institute of Agricultural Economics, Sofia, BULGARIA, E-mail: hbachev@yahoo.com 


\section{Introduction and overview}

The importance of "good governance" for achieving and maintaining the overall and the particular (agrarian, food-chain, forest, industrial, mining, transport, etc.) sustainability has been widely highlighted and increasingly studied in the last two decades (Astleithner and Hamedinger, 2003; Barnes and Hoerber, 2013; Brouwer, 2004; Clapp and Fuchs, 2009; Clune and Zehnder, 2018; Djanibekov and Valentinov, 2018; Duxbury and Jeannotte, 2012; EU, 2019; Falkner and Kalfagianni, 2009; Ferrero-Ferrero, 2015; Fransen, 2015; Hajjar et al., 2019; Gibson, 2010; Gleeson, Darbas, Lawson, 2004; Landert et al, 2017; Lawrence, 2005; Marsal-Llacuna, 2016; McClintock, Miewald, McCann, 2018; McLeod-Kilmurray, 2011; McMichael, 2011; Monkelbaan, 2018; Newton, Agrawal, Wollenberg, 2013; O'Shea, 2011; Sar, 2018; Schouten and Bitzer, 2015; Siegel and Lima, 2020; Thrän et al, 2020; OECD, 2011; UN,2015; UNEP, 2020). Diverse systems for assessing the quality of (sustainability) governance at the corporate, city, sectoral, territorial, national, meta, etc. levels have been suggested (Clapp and Fuchs, 2009; Ferrero-Ferrero, 2015; Fransen, 2015; Gibson, 2010; Landert et al, 2017; Marsal-Llacuna, 2016; OECD, 2011; Shell, 2020; Uniliver, 2020), sustainability impact of various (public, private, international, etc.) modes of governance assessed (Brouwer, 2004; Djanibekov and Valentinov, 2018; Falkner and Kalfagianni, 2009; Fransen, 2015; Gleeson, Darbas, Lawson, 2004; McLeod-Kilmurray, 2011; McClintock, Miewald, McCann, 2018; Newton, Agrawal, Wollenberg, 2013; Sar, 2018; Schouten and Bitzer, 2015;), a new company, sectoral, intersectoral, urban, rural, national, transnational, etc. forms and models of (sustainability) governance designed and declared (Astleithner and Hamedinger, 2003; Duxbury and Jeannotte, 2012; Hawkes, 2011; Hajjar, 2019; Lawrence, 2005; McMichael, 2011; Newton, Agrawal, Wollenberg, 2013; Monkelbaan, 2018; O'Shea, 2011; Shell, 2020; Thrän et al, 2020; EU, 2019; UNEP, 2020; Uniliver, 2020). Simultaneously, a wide range of (sustainability) governance "failures" in many directions have been detected (Bachev, 2010; Hajjar, 2019; Lawrence, 2005; Monkelbaan, 2018; Siegel and Lima, 2020). For instance, failures to "deal" with (govern) effectively climate change and environmental degradation have been widely recognized; currently entire industries without an effective system of (risk, crisis, etc.) governance are facing collapse because of the on-going Covid-19 pandemic, etc.

Despite that unprecedented incorporation of sustainability into governance, however, a "three pillars" (economic, social, and environmental) system for understanding and assessing sustainability have been dominating, including in the agrarian sphere (Cruz et al., 2018; EC, 2001; FAO, 2013; Hayati et al., 2010; Kamalia et al., 2017; Lopez-Ridauira et al., 2002; Lowrance et al., 2015; OECD, 2001; Sauvenier et al., 2005; Singh et al., 2009; VanLoon et al., 2005). What has been a recent development is the inclusion of governance into sustainability as a new "fourth" dimension, attribute, or pillar (aspect) of sustainability (Barnes and Hoerber, 2013; Boström, 2012; Diebecker and Sommer, 2017; Filho et al, 2016; Crowther, Seifi, Wond, 2019; Kassem et. al, 2016; Mutisya and Yarime, 2014; Miralles-Quirós et al, 2018; Monkelbaan, 2017, 2018; Parra and Moulaert, 2011; Whitehead, 2017; Worrall et al., 2009). The codes, standards, and performance indicators for "good governance" have been widely accepted to characterize the state of sustainability and be a goal of sustainable development by researchers, private corporations, 
professional organizations, local and national governments, international organizations, etc. (Altinay, 2012; ASA, 2019; Baeker, 2014; Bond et al., 2011; Bosselmann et al., 2008; Burford, 2017; City of Brooks, 2019; Diebecker and Sommer, 2017; Fraser et al., 2006; EU, 2019; IFAD, 1999; Iturriaga, 2009; Gibson, 2006; Kayizari, 2018; Monkelbaan, 2017; Scobie and Young 2018; RMIT University, 2017; Simberova et al., 2012; Shell, 2020; UN, 2015; UCLG, 2014; Whitehead, 2017).

Nevertheless, up to date, there is no consensus on many important issues such as: what is the governance sustainability; how to measure governance sustainability; how to integrate the governance into the overall sustainability; what are critical factor determining one or another level of governance sustainability, etc. Most often missing (fourth) governance pillar of sustainability is related to the political system (Worrall et al., 2009), democratic governance (Parra and Moulaert, 2011), dominating values and frame system (Mutisya and Yarime, 2014), or a broader "institutional" dimension (Boström, 2012), corporate governance performance (Kassem et. al, 2016; MirallesQuirós et al, 2018), corporate executives' and public sector's capacity, responsibility and accountability (Filho et al, 2016; Crowther, Seifi, Wond, 2019), etc. There have been suggested multiple indicators for governance sustainability measurement at the national and international levels such as state of the formal institutional environment, implemented policies and strategies, human resources development, built capacity, governance of public organizations, the inclusion of stakeholders in public decisionmaking, etc. (Bell and Morse 2008; Bhuta and Umbach, 2014; CoastalWiki, 2019; Diebecker and Sommer, 2017; Ganev et al., 2018; Iturriaga, 2009; Monkelbaan, 2017; Spangenberg et al., 2002; Whitehead, 2017).

However, a good portion of suggested approaches for assessing governance sustainability are at a conceptual level or based on qualitative and experts' analysis without measuring the sustainability level and integrating it into the overall sustainability. Others contain a small number of "arbitrary" selected "universal" indicators not taking into account specific socio-economic, institutional, natural, etc. conditions of individual countries and different industries (sub-sectors), regions, ecosystems, and types of organization of activity (Bachev, Ivanov, Sarov, 2020). Very rarely a holistic approach for assessing and integrating diverse (social, economic, environmental, etc.) pillars of sustainability is applied while stainability principles, criteria, and indicators are often incorrectly confused. Most frameworks are incomplete since they limit assessments to formal institutions and/or public forms, while important market, private, and "informal" governance are ignored. Usually, an assessment is made only at the national or international level, without offering an approach that takes into account the specifics of agricultural systems of different types - agricultural subsectors, agro-regions, types of agro-ecosystems, types of farming systems and forms of agro-organization. In general, the "historical" approach and assessment of past states prevails, rather than orientation towards (assessment, prediction of) the future essential for this category. The latter impede the assessment of (governance) sustainability to become a tool and criterion for directing changes in public policies and strategies of interested agents and stakeholders. Last but not least, many frameworks are complex to understand and for practical use by decisionmakers, which deters widespread use in everyday management practice.

In Bulgaria, a little comprehensive research on the relationship between governance and sustainability has been carried out, including in the agrarian sector (Bachev 2005, 2010, 2018; Bachev et al., 2016; Bachev and Terziev, 2018; Sarov, 2019). In fact, studies on governance aspects of agrarian sustainability are at the 
beginning stage (Bachev, 2017, 2018; Bachev et al. 2020; Sarov, 2019;). Therefore, elaboration of a holistic framework for defining and assessing the governance sustainability in general and in agriculture, in particular, is a topical academic and practical (policies, businesses, and collective actions forwarded) task. The goal of this article is to present such a framework for the contemporary conditions of Bulgarian agriculture and estimate the level of governance sustainability at national, subsectoral, regional, ecosystem, and farming organization levels.

\section{Methodology}

\section{Why a new (governance) pillar and what is governance sustainability?}

Apart from the "practical" drivers that incorporate governance as a new fourth pillar of sustainability, there is pure "theoretical" justification (reason) as well. There are five major approaches for understanding agrarian sustainability - as "alternative ideology" (Edwards et al., 1990; VanLoon et al., 2005); as a "new strategy" (Mirovitskaya and Ascher, 2001); a "characteristic" of agricultural systems such as "ability to achieve diverse goals "(Brklacich et al., 1991; Hansen, 1996) or "capacity to maintain and improve its functions "(Lopez-Ridaura et al., 2002 Lewandowski et al., 1999); or a "process of understanding and adapting to change" (Raman, 2006). The "new" governance pillar is immanent to agrarian sustainability, regardless of the approaches to define it in scientific literature and managerial practices (Table 1).

Table 1. Correspondence of New Governance Pillar to Principle Approaches for Defining Agrarian Sustainability

\begin{tabular}{|l|c|}
\hline Approaches to defining (agrarian) sustainability & $\begin{array}{c}\text { Governance Pillar } \\
\text { relevance }\end{array}$ \\
\hline Alternative ideology & $\sqrt{ }$ \\
\hline A new strategy and "management approach" to farming & $\sqrt{ }$ \\
\hline Ability to achieve diverse goals & $\sqrt{ }$ \\
\hline Potential to maintain and improve its functions & \\
\hline Process of understanding and adaptation to changes & \\
\hline
\end{tabular}

Source: author

In addition to "new approaches" to farming (such as organic, ecological, biodynamic, conserving, regenerating, community-supporting, etc.), sustainability "movements" and (later on) "ideology" presently include various "social" issues (e.g. forms of consumption; a way of life; decentralization; development of communities; equality of genders, groups, countries, and generations; preservation of culture and heritage; animal welfare, etc.), and among them, the "good social and business governance" is widely accepted as "universal principle" (UN, 2015).

In another understanding of agricultural sustainability as a "set of strategies" and "management approaches" (use of farm and local resources; reduction of chemicals; diversification; reducing animals in pastures; good agricultural practices; circular economy; payment for eco-damages, etc.), the governance aspect is also dominant and ensures the implementation of certain strategies through adequate farming management. 
In another approach, which characterizes the sustainability of agricultural systems as "ability to meet multiple goals overtime" (e.g. food security, conservation of natural environment, minimum living standards, etc.), good and democratic governance (with participation and of interest of all stakeholders), is increasingly present in the documents of international, state, non-governmental, business, and public organizations, along with social, economic, environmental, cultural, etc. goals of sustainable development.

In the widespread approach of linking sustainability to the (agricultural) system itself and its ability to function in the future (maintain and improve its economic, social, environmental, etc. functions), effective governance is also imminent. Namely the latter critical "attribute" (characteristic) of the system (along with stability, resilience, reliability, productivity, quality, energy efficiency, social justice and acceptability, etc.), ensures the appropriate use and effective preservation and development of "factors" of agricultural production.

Most recently sustainability increasingly is perceived as "a process of understanding and adapting to change", a consequence of the constant evolution of sustainability concept and agricultural systems. Accordingly, understanding of sustainability is always specific to time, situation and element, and characterizes the potential of agricultural systems to exist and develop by adapting to and incorporating changes in time and space. For instance, respecting the "rights" of farm and wild animals, granting legal rights to entire ecosystems, etc. are presently important attributes of agricultural sustainability. Such novel understanding also includes the effective "management" of activities, relations, impacts, adaptation, transformation, and modernization in the concept of agricultural sustainability.

Therefore, all modern approaches imply or require the inclusion of the governance dimension, attribute, or aspect of agrarian sustainability. Nevertheless, it is still a challenge to define the governance pillar of agrarian sustainability and its distinction from agrarian governance and sustainability of governing structures (Bachev, 2018).

Sustainability of agriculture is a "systemic characteristic" of agricultural systems characterizing "ability to continue over time" (Hansen, 1996; Bachev, 2005, 2010). Actually, instead just as a "state" of the system (Monkelbaan, 2018), sustainability is better to be perceived as a process as well, since agriculture (agricultural production) is a process of interaction between people and people and nature. Thus sustainability of represents the ability of agriculture (agricultural production) to exist over time maintaining its socio-economic and natural base. More precisely, it characterizes the ability of agriculture (internal capacity and adaptability to constantly changing external natural, market, institutional, etc. environment) to exist over time and maintain effectively its economic (income generation, etc.), social (providing employment, satisfaction, etc.) and environmental (conservation, recovery, improvement, etc.) functions.

Besides, modern agriculture production (agricultural sector) is a social (management, production and exchange) system and like all social systems has as inseparable and immanent part a system (a fourth "function") of governance. Thus sustainable agriculture is to be able to maintain effectively its governance function as well, while agrarian sustainability has four equally important aspects (pillars) governance sustainability, economic sustainability, social sustainability, and environmental sustainability (Figure 1).

Commonly there is no "perfect" governance, and therefore the achievement of a sustainability goal for "good governance" (UN, 2015) or sustainable development, 
also require management (governance) - a process of transition or "transitional governance" (Monkelbaan, 2018) toward achieving a good governance sustainability. Former communist countries from East and Central Europe are good examples in that respect, since transition of the previous model to modern European Union system of governance has taken several decades (and still incomplete in some respects).

It is obvious that the governance sustainability of agriculture has to be connected with (and characterize) the specific system of governance in the sector. For other pillars agrarian sustainability is primarily associated with stability or preservation of status quo - e.g. good environmental sustainability relates to the preservation of the natural environment, good social sustainability to the preservation of traditional forms, technologies, customs, etc. However, unlike the literal meaning of the word and other pillars of agricultural sustainability, (good) governance sustainability does not necessarily mean "unchangeability" of the governance system over time. On the contrary, very often the preservation and improvement of agrarian sustainability and realization of socially desired sustainability goals require progressive changes (rejection, modernization, transformation) of the existing governance system, and often the introduction of a "new model" of management (governance). For example, in the last 30 years in Bulgaria and other East European countries of the former communist bloc, the previously existing inefficient and unsustainable model of (general and agrarian) governance has been fundamentally transformed by introducing the European Union legislation, market mechanisms, private ownership, etc. Contemporary challenges related to climate change, globalization, democratization, pandemics, etc. also necessitate constant improvement of the governance system in order to realize the multilateral principles and goals of sustainable development. For example, the ambitious new Green deal of EU and related Farm to Food Strategy put high mid and long-term objectives calling for fundamental reform of CAP of EU and its governance (EC, 2020).

Governance sustainability of agriculture is (has to be) related to another essential attribute of the sector's governance system - namely its quality and compliance with current and future needs of the industry (Bachev, Ivanov, Sarov, 2020). Sustainability is associated with a certain type of governance - namely effective governance for the specific and constantly evolving conditions of a particular agro-system. The long-term experience of Bulgaria and around the world proves that agricultural sustainability and sustainable development, in general, are not achieved automatically, as a ("side") result of private entrepreneurship, market competition, and government intervention. On the contrary, there are numerous private, market, public, public, etc. "failures". Theory and practical (positive and negative) experience demonstrate that achieving and maintaining agrarian sustainability and sustainable agrarian development requires an adequate (effective) governance system at different levels (economic, sectoral, ecosystem, regional, national, international, global) and in large time horizons (Bachev, 2010).

Achievement of each of the particular goals of sustainable development presupposes (imposes) a specific system of governance - e.g. social sustainability needs appropriate "social" governance, economic sustainability requires effective economic governance, environmental sustainability necessitate relevant ecogovernance, etc. (Bachev, 2010) Consequently, a statement like "governance" sustainability requires an appropriate "governance" system seems a little bit strange.

Sustainability gives insight not on past trends or even current situations but it is "future-oriented". Besides, achieving the socially desired goals of "good governance" ("global social contract") also requires specific management (governance). In addition 
to particular (socio-economic, environmental, etc.) parts of the overall governance, the governance sustainability also characterizes how the entire system works and weather in complies with, drives towards, and reconciles diverse social goals, preferences, norms, and expectations at every particular stage of development.

Furthermore, besides specific social, economic, environmental, etc. elements, governance sustainability takes into account the absolute and comparative efficiency of the governance system of agro-systems of different types (Bachev, 2010). Very often, due to poor and inefficient governance, the opportunities (potential) for improving social, economic, or environmental sustainability are not fully realized. There are also many examples when the planned social, economic, and environmental goals (level of sustainability) are reached at the "price" of too many total (production, transaction, direct, indirect, private, collective, public, social, etc.) costs. In all these cases, there is a feasible more effective alternative governance system that can increase the governance and the overall sustainability of the sector.

Therefore, there is no contradiction but a significant difference between "sustainability governance" and "governance sustainability". The former indicate "how" a particular (aspect) or overall sustainability is managed (specific tools, modes, mechanisms, etc.), maintained, or improved. The latter assesses the state and the ability (potential) of the system to maintain and improve its governance and sustainability - thus indicates "whether" sustainability will be achieved and the "type of development" realized. There are many examples when countries achieve high economic sustainability while governance sustainability is low since free market mechanisms are suppressed, private initiatives and modes are restricted, large grey and black sector dominate, high standards of public governance are not applied, wide representation of all interested parties in decision making not put in place, etc. and consequently the "long-term" sustainability of the system compromised.

Good governance does not come automatically but require proper "management" (Bachev et al., 2020; Monkelbaan, 2018). While aspect (economic, social, environmental) governance comprise specific mechanisms and modes for maintaining or achieving a particular level of (good) economic, social, or environmental sustainability, the governance sustainability shows "how the system of governance works" and efficiency of the governance, including a wide range of contemporary managerial, political, ethical, social, economic, international, intra and intergenerational, etc. issues. Therefore, governance sustainability characterizes the efficiency of the specific system of governance of a particular agro-system (European, national, sub-sectoral, ecosystem, regional, type of farming organization, etc.) (Bachev et al., 2020). Accordingly, "good governance" means high governance sustainability, while "poor" (ineffective) governance corresponds to low governance sustainability.

Governance sustainability is both a basic system characteristic, a goal of sustainable development, and a means to achieve the multiple goals of the system and the "states" of economic, social, environmental, governance etc. sustainability (the number of "pillars" of sustainability is constantly expanding, including institutional, cultural, moral and ethical, etc. aspects (Boström, 2012; Duxbury and Jeannotte, 2012; Hawkes, 2001; Nurse, 2006). Given its importance for achieving, maintaining, and improving overall agricultural sustainability, it can be said that governance sustainability is the "first" (pillar) between (four) "equal" pillars. Namely, governance sustainability "maintains" the integrity of the system (Figure 1), guarantees its harmonious "development", ensures efficiency, "co-measurement" and proper management, and ultimately the realization of the diverse and often opposing goals 
(aspects) of sustainability. For example, the contradictions between economic and social goals (high economic growth, income, etc.) and the preservation of the natural environment (pollution and destruction of environmental resources) are well known.

Maintaining the multiple functions (sustainability) of agriculture requires an effective social order (good governance) that is linked to the governance pillar of sustainability. This "order of sustainability" includes a system of various (governance) mechanisms and forms that regulate, coordinate, stimulate and control the behavior, actions, and relationships of individual agents at different levels - farm, local, regional, national, transnational, global (Bachev, 2010). In the special literature and evaluation practice, however, governance sustainability is often associated only with "external" (for agricultural agents or the sector) forms - the European Union, international organizations, the state, local government; or only with a certain form of governance - the government; or only with public forms (such as public interventions, programs, etc.); or only with formal structures, etc. (Worrall et al., 2009; Parra and Moulaert, 2011; Mutisya and Yarime, 2014; Boström, 2012; Kassem et. al, 2016; Miralles-Quirós et al, 2018; Filho et al, 2016; Crowther, Seifi, Wond, 2019; Bell and Morse 2008; Bhuta and Umbach, 2014; CoastalWiki, 2019; Diebecker and Sommer, 2017; Ganev et al., 2018; Iturriaga, 2009; Monkelbaan, 2017; Spangenberg et al., 2002; Whitehead, 2017. For example, due to the similar English spelling and pronunciation the "Governance" is often confused with the "Government", even by established scholars, and it is widespread among the public and professionals.

However, there is growing talk about the need and importance of environmentally friendly, socially responsible, and good governance performance by private organizations, corporations, producer organizations, non-governmental organizations, civil society organizations, and local authorities, etc. There is an increasing emphasis on the need for "cooperation" between the various forms of governance (publicprivate, cross-sectoral, transnational, etc. partnership) to achieve the desired sustainability. The assessment of the governance sustainability of agriculture is to include all forms of governance - institutions, market, private, public, hybrid, formal, informal, national, transnational, simple, complex, multilevel, etc., and take into account their complementarity, dependency, contradictions, particular and total efficiency, etc. (Bachev, 2010).

Therefore, the principal forms and mechanisms that make up the system of governance of agricultural systems of different types are to be well defined. The system of governance of agriculture comprises of several principal components, all of which have to be included in the sustainability assessment: First, institutional environment or "rules of the game" (Furuboth and Richter, 1998; North, 1990) - that is the distribution of de-factor (formal and informal) rights and obligations between individuals, groups, and generations and the (formal and informal) system(s) for the enforcement of rights and rules. Second, market forms and mechanisms ("market order", "the invisible hand of the market) - various decentralized initiatives driven by the movement of free-market prices and market competition like a spot-light exchange, a classical sale or lease, trade with special high-quality, organic, etc. products and origins, agro-ecosystem services, etc. Third, private forms and mechanisms ("private or collective order") - diverse private initiatives and special contractual and organizational forms (long-term supply and marketing contracts, voluntary eco-actions, voluntary or mandatory codes of conduct, partnerships, associations, trademarks, labels, etc.). Forth, public forms and mechanisms ("public order") - various public (community, state, international) interventions in the market 
and private sector such as recommendations, regulations, support, taxation, financing, provision, modernization of rights, and rules, etc.

Agriculture consists of various types of agro-systems - from individual "farmland plot", entire "farm", specific "agroecosystem", geographical "agro-region", to "national", "European" and "global". The farm is the lowest level at which the management and organization of agricultural activity (and sustainability) takes place, and where all aspects of sustainability are "realized" and can be assessed (Bachev, 2005). Therefore, the farm rather than smaller agro-systems within the farm's borders, is the first level for assessing agrarian (economic, governance, integral, etc.) sustainability. Many holistic sustainability assessment systems place the smallest ecosystem (a "separate plot of agricultural land", a "lake", etc.) as the lowest (first) level of sustainability assessment in agriculture (Sauvenier et al., 2005). We have proved that while for certain aspects (ecological, partly economic) of sustainability such calculations are useful, for most of them they have no practical (in particular managerial) meaning (Bachev 2005).

Identification or mixing of sustainability of agriculture (incl. governance) and sustainability of organizational and governance structures in the sector is also widespread (Ivanov et al., 2009; Sarov, 2019; Sauvenier et al., 2005). A clear distinction is to be made between governance sustainability of agriculture and sustainability of governance structures in agriculture (Bachev, 2018). While sustainability of a certain type of farm (e.g. "family farms") is included as a main criterion for assessing "social" (pillar of) sustainability, the specific level of sustainability of individual management structures (e.g. different types of farms, producer organizations, administrative structures, etc.) is not a part of or related to the assessment of agricultural sustainability. Sustainable development is usually associated with adaptation of farms and other governing structures to constantly evolving socioeconomic, market, institutional and natural environment. The latter process is accompanied by declining importance ("sustainability") or liquidation of certain types of farms (public, cooperative, small in size), restructuring and modernization of farming organizations and agricultural administration, and emergence of various complex, vertically integrated and hybrid forms of management, etc. Modern approach for assessing sustainability of agricultural farms has been proposed in our previous publications (Bachev, 2018).

On the other hand, governance sustainability of agriculture expresses ("effectiveness" of) the condition and contribution (to achievement of the goals of sustainable development) of the basic governing mechanisms and forms of analyzed agro-system. Most of these mechanisms and forms of governance impact the specific governing structures used by individual agents (including farms, farmers' organizations, contractual and vertically integrated forms) and their sustainability. But many of them are related to (farmer's relations with and) other agricultural agents (resources owners, hired labor, inputs suppliers, processors, retailers, end consumers, agrarian administration, etc.), while some relate to inter-organizational/farming elements (e.g. enforcement of labor, food safety, animal welfare, environmental, etc. standards). 
Figure 1. System for Assessing Governance and Integral Sustainability of Bulgarian Agriculture

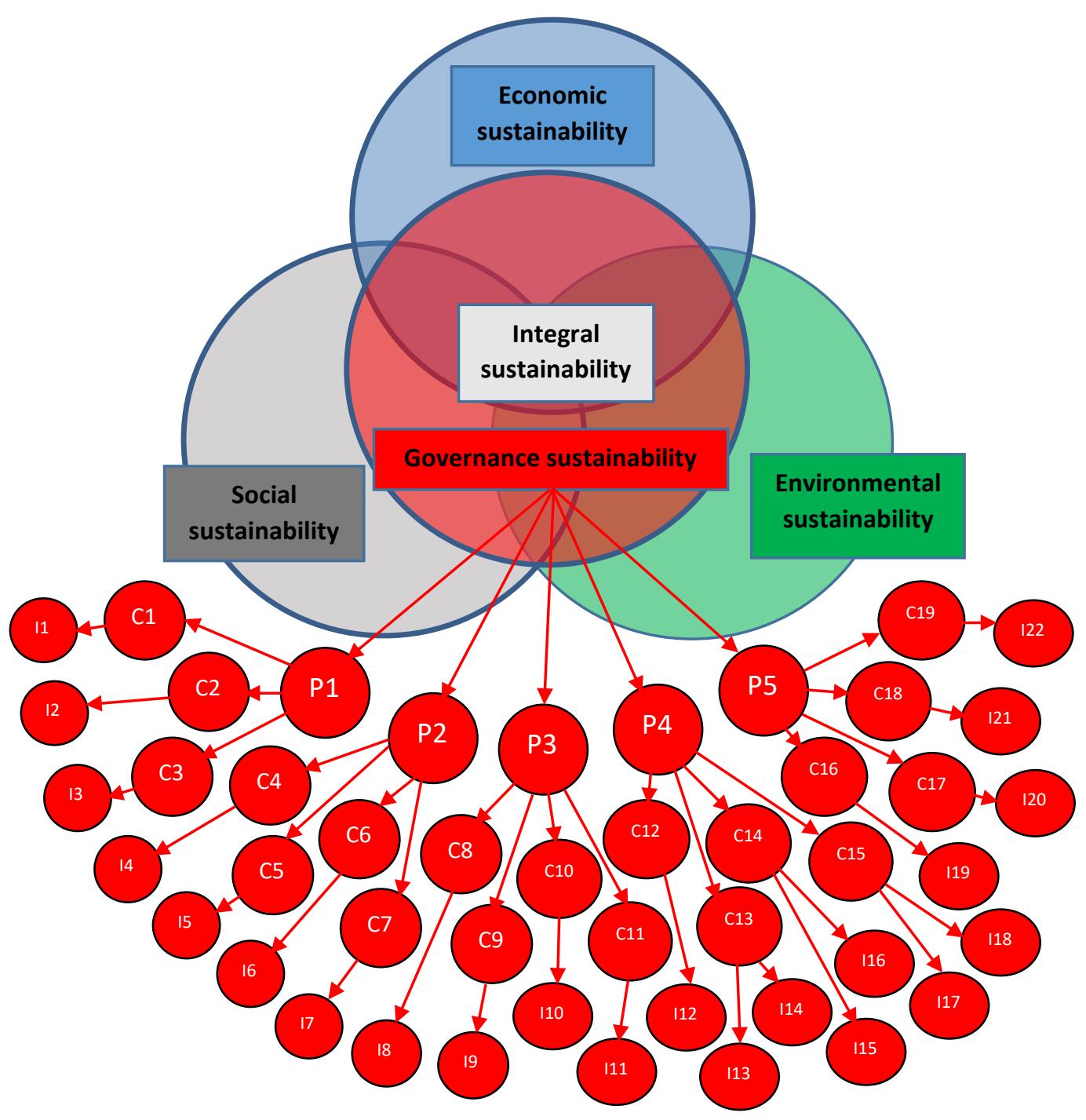

Source: author

\section{Holistic system for assessing agricultural sustainability}

A holistic approach for assessing sustainability of agricultural system (Sauvenier et al., 2005) is incorporated for identifying the system of indicators for assessing the governance, economic, social and environmental sustainability of Bulgarian agriculture. A hierarchical system of specific for the condition of Bulgarian agriculture principles, criteria, indicators and reference values for each aspect (pillar) of sustainability is elaborated (Figure 1).

Principles of governance sustainability are "universal" and represent states of sustainability that must be achieved or maintained. For the "specific" contemporary conditions of Bulgarian (and European Union) agriculture the following five principles of governance sustainability are identified, related to the principle (five) 
mechanisms and forms of governance: "Good legislation", "Democracy of management", "Working Agrarian Administration", "Working Market Environment", and "Good Private Practices".

Criteria of governance sustainability are precise standards for each Principle, representing the effective state of evaluated system when the respective principle is implemented. For the modern conditions of Bulgarian agriculture 20 criteria for assessment of various aspects of governance sustainability are determined. For example, for the principle "Democratic management" three criteria have been selected by experts - "Representation", "Transparency" and "Impact".

Indicators of governance sustainability are quantitative and qualitative variables, which can be easily evaluated in the specific conditions of a particular agro-system and measuring the compliance with a given Criterion. Indicators have been selected after multi-criteria assessment by experts using a system of criteria such as "Relevance to reflecting aspects of sustainability", "Discriminatory power in time and space", "Analytical soundness", "Intelligibility and synonymity", "Measurability", "Governance and policy relevance", and "Practical applicability" (Sauvenier et al., 2005). As a result, a system of 22 indicators for assessing governance sustainability of Bulgarian agriculture has been determined. For example, for criterion "Impact" the indicator "Share of subsidies in income" is selected. The same approach has been used for identifying the indicators for assessing economic, social and environmental pillars of agrarian sustainability in Bulgarian - 12, 16 and 17 accordingly.

Reference values for governance sustainability are preferred levels for each indicator in accordance with the specific conditions of a particular agro-system. They show the level(s) at which long-term governance sustainability is "guaranteed" and improved. Depending on degree of reaching the Reference value, an agro-system may have "high", "good", or "low" sustainability, or be "unsustainable". For example, an agricultural system with higher than $40 \%$ of subsidies in income is highly sustainable, while under 5\% unsustainable when it comes to "Impact".

Integral Governance and Overall sustainability is calculated after transforming specific levels for each indicator into a Sustainability Index using an appropriate scale for each indicator (Bashev et al. 2020). Example for transforming a qualitative and a quantitative indicator into "unitless" index is presented in Table 2.

Table 2. Transforming Specific Values of Indicators into Sustainability Index and Determining Sustainability Level

\begin{tabular}{|c|c|c|c|c|}
\hline Measures & $\begin{array}{c}\text { I7 - Farmer's } \\
\text { participation } \\
\text { in decision- } \\
\text { making }\end{array}$ & $\begin{array}{c}\text { I17 - Lands } \\
\text { concentration }\end{array}$ & $\begin{array}{c}\text { Sustainability } \\
\text { Index }\end{array}$ & $\begin{array}{c}\text { Sustainability } \\
\text { level }\end{array}$ \\
\hline \multirow{3}{*}{$\begin{array}{l}\text { Specific } \\
\text { value/Scale }\end{array}$} & High & Bellow 200 ha & $1-0,81$ & High \\
\cline { 2 - 5 } & Good & $200-400$ ha & $0,8-0,5$ & Good \\
\cline { 2 - 5 } & Satisfactory & $400-600$ ha & $0,49-0,26$ & Satisfactory \\
\cline { 2 - 5 } & Unsatisfactory & $600-800$ ha & $0,25-0,06$ & Unsatisfactory \\
\cline { 2 - 5 } & None & Above 1000 ha & $0,05-0$ & Nonsustainable \\
\hline
\end{tabular}

Source: author

Integral Index of a particular Criterion, Principle, and Aspect of Sustainability, and Integral Sustainability Index of Agriculture are arithmetic averages of the indices of constituent components. Integral indices are calculated by applying "equal weight" 
to each indicator in a given criterion, to each criterion in a given principle, and to each principle in every pillar. The latter is determined by the fact that individual aspects, and indeed principles of sustainability, are "by definition" equally important for agricultural sustainability. Moreover, differentiation of weights of individual criteria in each principle and individual indicators in each criterion is difficult to justify, and practically unimportant since number of indicators is large while relative contribution small. Sustainability level is determine using scale defined by experts (Table 2).

Elaborated framework for assessing governance sustainability of Bulgarian agriculture has been tested by using results of a 2018 survey with managers of 208 "typical farms" of different size, legal status, production specialization, and ecological and geographical location. Surveyed holdings represents around $0,3 \%$ of all registered agricultural producers in the country. Physical Persons consists 93,4\% of surveyed farms, Sole Traders 2,8\%, Cooperatives $1,9 \%$, and Companies 1,9\%. Structure of surveyed farms approximately coincides with the real structure of farms of different categories in Bulgaria. Aggregate index of (aspect and integral) sustainability for each specific agro-system (agricultural sub-sector, agro-ecosystem, agro-region, and type of farming organization) is calculated as an arithmetic average of indices of constituent farms in the respective system.

\section{Results and Discussion}

\section{Level and importance of governance sustainability of Bulgarian agriculture}

Governance sustainability of Bulgarian agriculture is at good level but nevertheless close to the border with an inferior (satisfactory) level (Figure 2).

Figure 2. Governance, Economic, Social, Environmental and Integral Sustainability of Bulgarian Agriculture

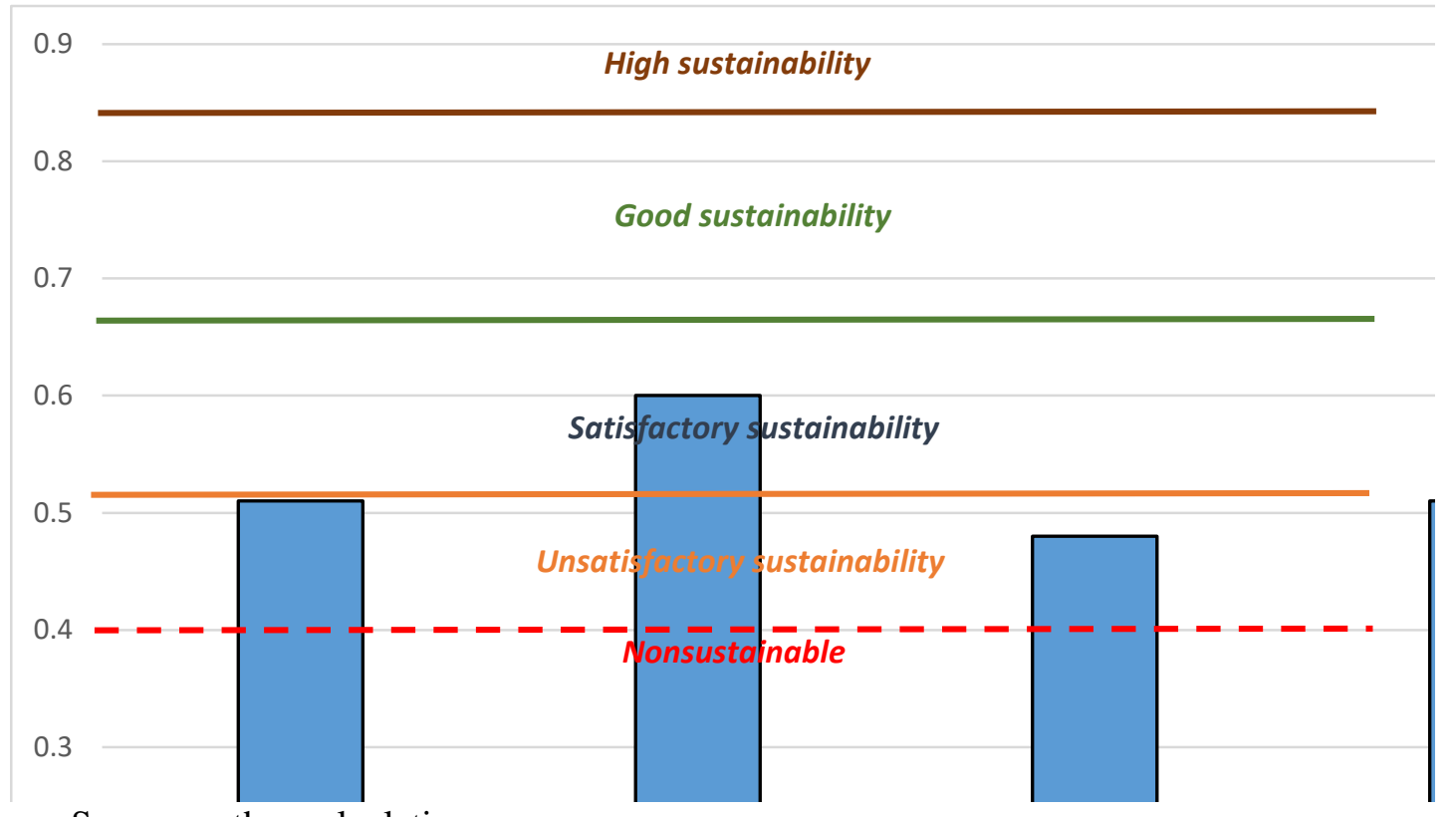

Source: author calculation

Inclusion of Governance pillar in the calculation of Integral agrarian sustainability changes insignificantly (by 0.005) Integral Sustainability Index of Bulgarian agriculture without modifying the overall good sustainability level (Figure 
3). Furthermore, in some sub-sectors (such as Vegetables, Flowers and Mushrooms, and Livestock), some types of agro-ecosystems (Mountainous with Natural Constraints), some administrative and geographical areas (North-Central Region), and some types of farming organizations (Physical Persons, Cooperatives), inclusion of the Governance pillar in calculations for integral sustainability does not change or only slightly modify the Integral Sustainability Index and sustainability level. In most types of Bulgarian agro-systems, however, taking into account of governance sustainability lowers the Index (and level) of integral sustainability. Moreover, in semi-market sector (Farms Mainly for Self-sufficiency), integration of the Governance pillar is associated with qualitative "elevation" in the integral sustainability, turning the level from satisfactory to good. Therefore, inclusion of missing "new" and important Governance aspect is critical, as it improves the adequacy and accuracy of the assessment of agrarian sustainability at different levels.

Figure 3. Levels of Integral Sustainability of Bulgarian Agriculture with and without Inclusion of Governance Pillar

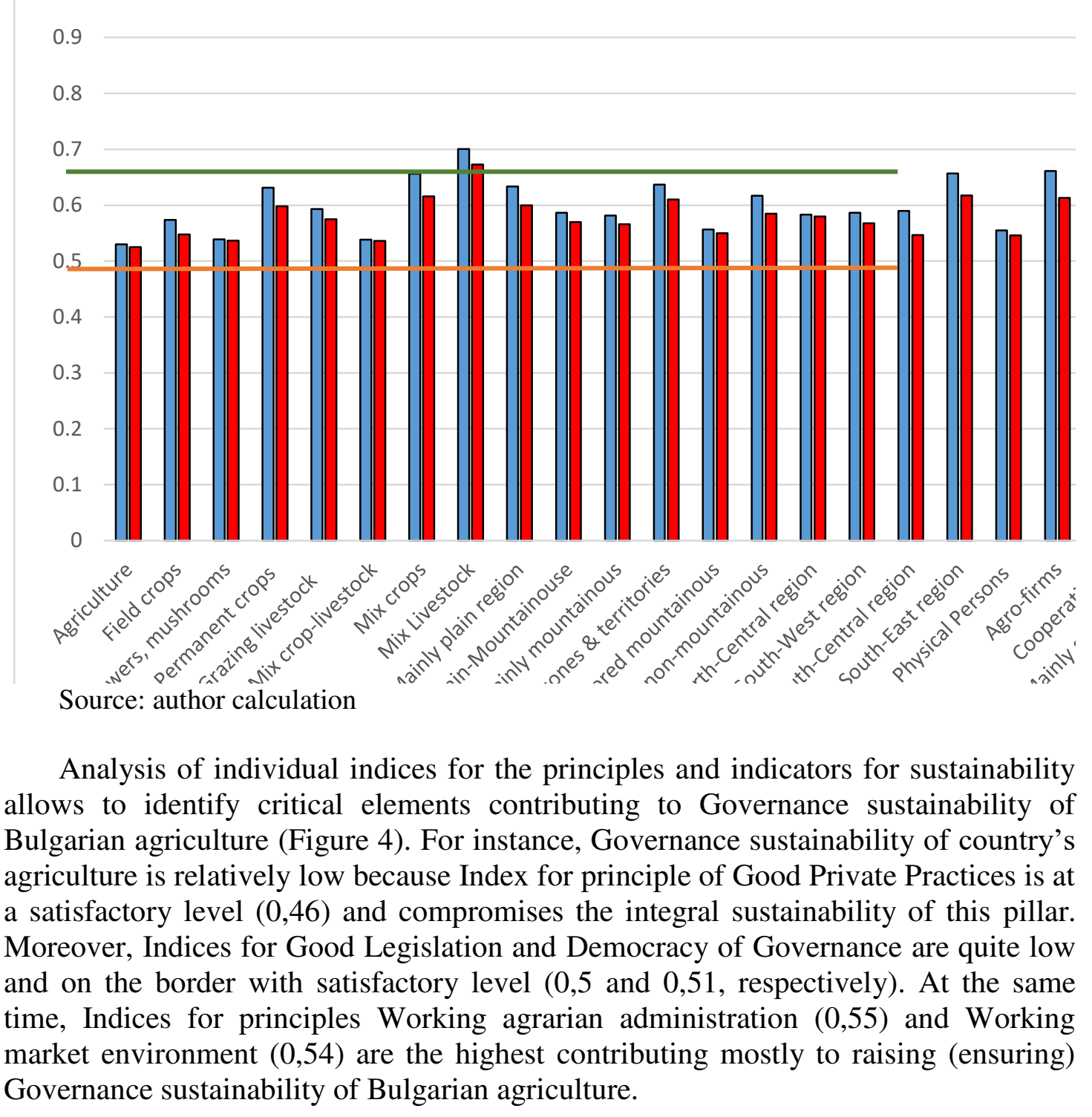


Figure 4. Sustainability Level for Major Principles of Governance Sustainability of Bulgarian Agriculture

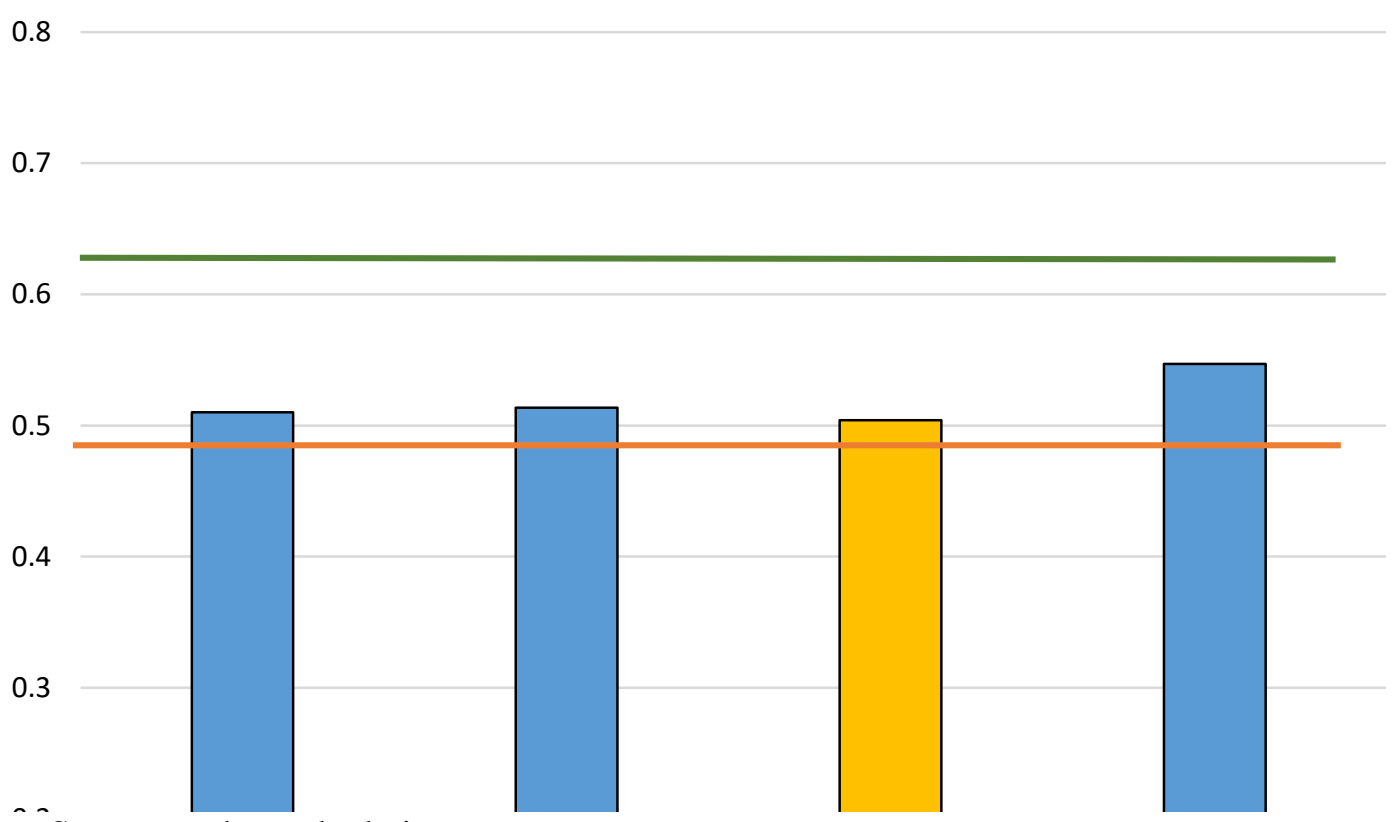

Source: author calculation

Individual sustainability indicators provide precise information about specific factors determining one or another value of a given sustainability Principle. Their analysis allows to specify the elements that increase or decrease Governance sustainability of Bulgarian agriculture for every principle and in general. For instance, insufficient Good Private Practices in country's agriculture are determined by insufficient Management Board External Control" $(0,38)$ and low Level of Informal System Efficiency" $(0,43)$. Similarly, although composite Index for principles Democratic Governance, Working Agrarian Administration and Working Market environment are at good levels, Indices for their respective indicators Farmer's Participation in Decision-making (0,31), Agrarian Administration Efficiency $(0,32)$, Administrative Services Digitalization $(0,36)$, and Possibility for Lands Extension $(0,37)$, are quite low at satisfactory levels.

Low values of Indicators help to identify areas that require improvement through adequate changes in institutional environment, public policies, modernization of agricultural administration, collective action and/or farm management strategies. At current stage, most critical for increasing Governance sustainability of agriculture would be progressive changes in: Farmers' Participation in Decision-making, Agrarian Administration Efficiency, Administrative Services Digitalization, Possibility for Lands Extension, Management Board External Control, Level of Informal System efficiency, Subsidies in Income, Extent of CAP Implementation, Acceptability of Legal Payments, and Land Concentration.

On the other hand, high levels of certain indicators show absolute and comparative advantages of Bulgarian agriculture in terms of good governance and sustainable development. At current stage, most favorable among them are: Representativeness in State and Local Authorities, Market Competition, Extent of Competitive Allocation of Public Resources, Access to Information, Extent of Awareness, and Administration Service Costs. 
Figure 5. Level of Indicators for Governance Sustainability of Bulgarian Agriculture ("Good-Satisfactory" border in red)

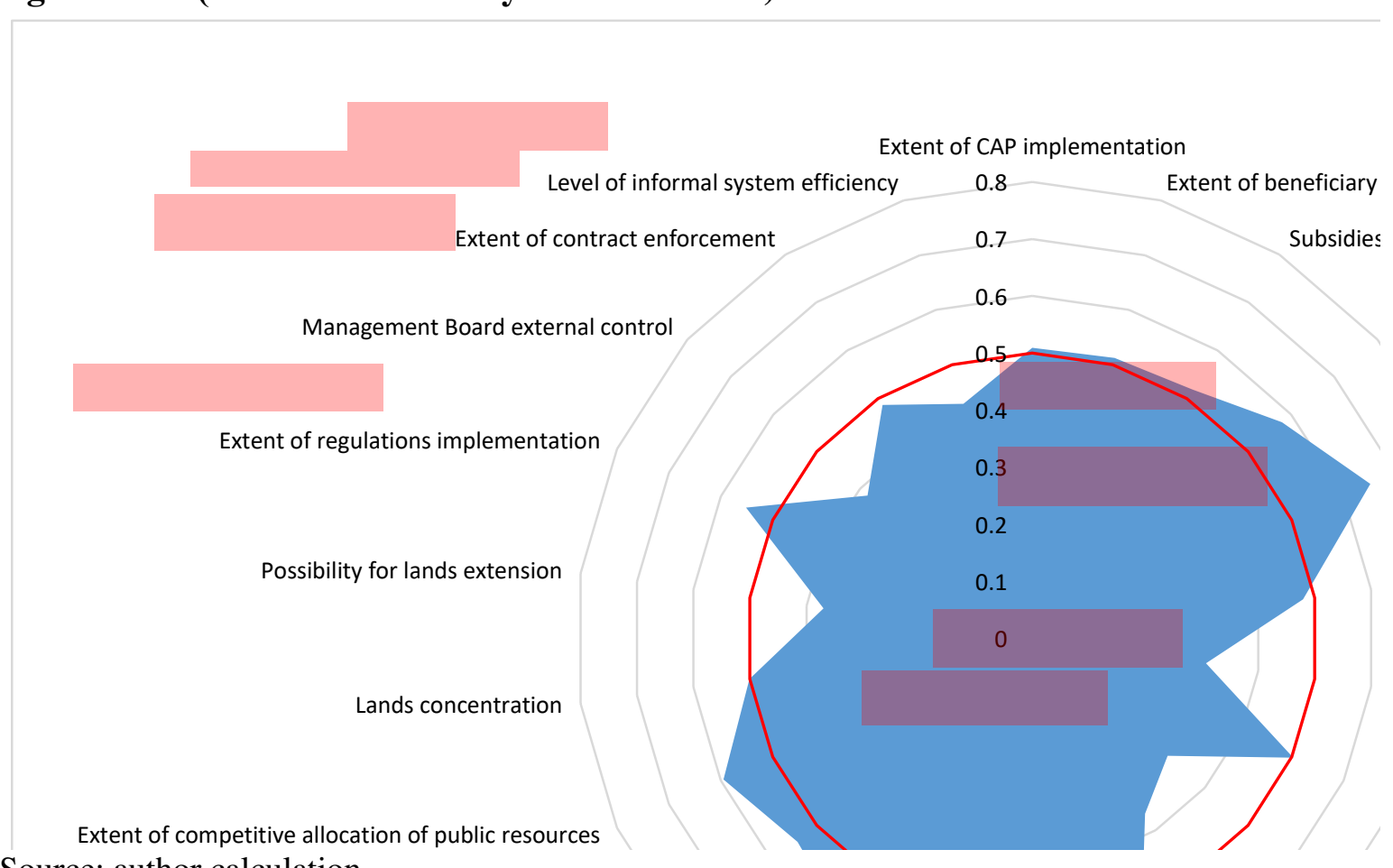

Source: author calculation

\section{State and factors of governance sustainability of major agro-systems in the country}

There is a large variation in the level of Governance sustainability of different type of agro-systems in Bulgaria (Figure 6). Mixed Livestock productions have the highest (good) level of Governance sustainability contributing to the greatest extent to improving (maintaining) overall Governance sustainability of Bulgarian agriculture. On the other hand, in Permanent Crops and Beekeeping the Governance Sustainability is below the national average and at the border with satisfactory level. Furthermore, in some major sub-sectors such as Field Crops and Mixed Crops, the level of Governance sustainability is in satisfactory territory. The latter sectors reduce to the greatest extent the integral Governance sustainability of country's agriculture. 
Figure 6. Level of Governance Sustainability of Different Type of Agro-systems in Bulgaria

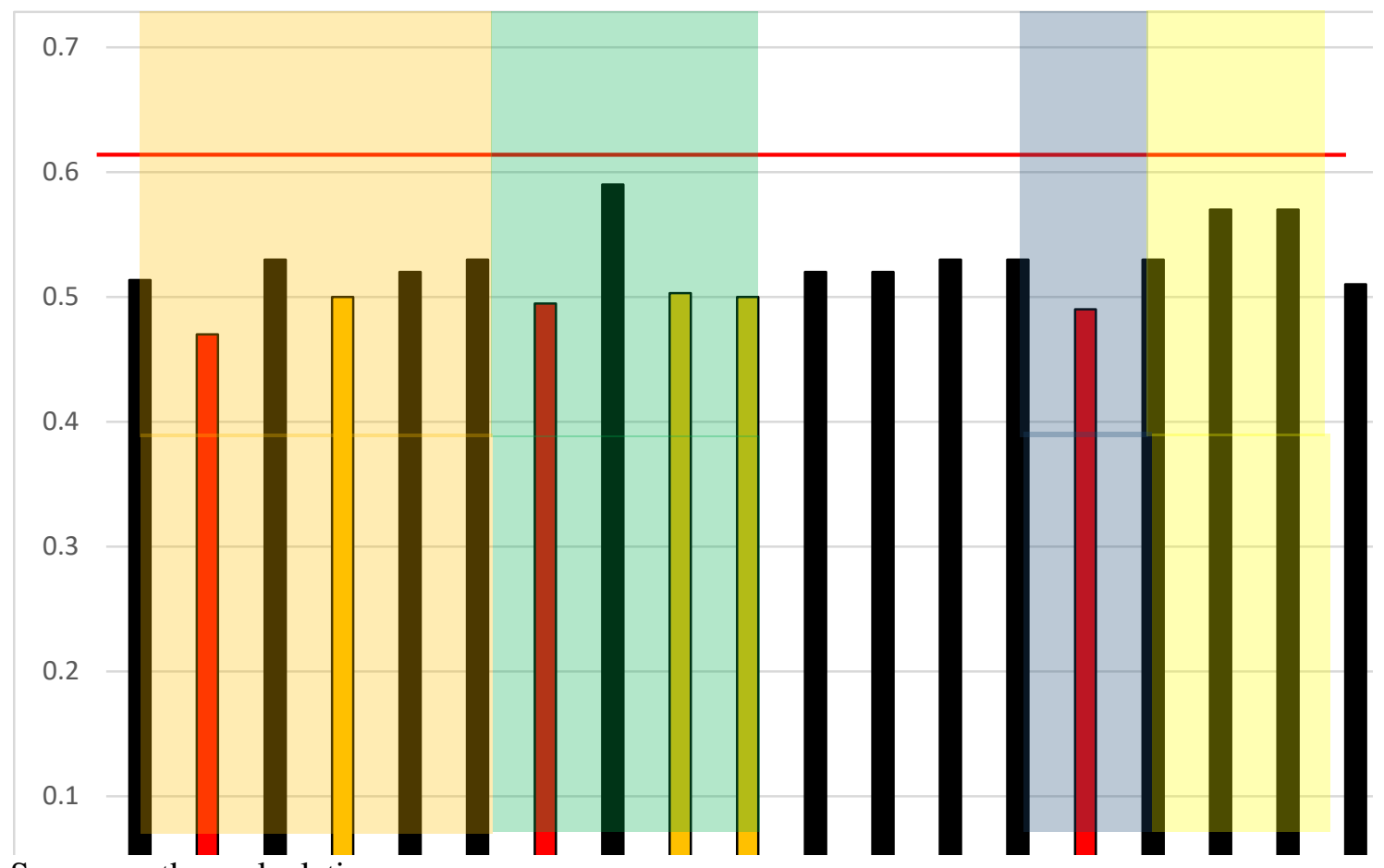

Source: author calculation

Highest (good) level of Governance sustainability is demonstrated in agroecosystems with Lands in Protected Areas and those in Mountain Areas with Natural Constraints. At the same time, Governance sustainability of agro-ecosystems Mainly Plain Region is at the border with satisfactory level, while in Non-Mountainous Region with Natural Constraints it is at unsatisfactory level. Thus the latter agroecosystems bring down to the biggest extent integral Governance sustainability of Bulgarian agriculture.

North-Central and Northeast agrarian (administrative) regions are with the highest (good) Governance sustainability, South-East region is at border to satisfactory level, while South-Central region is deep in satisfactory territory.

Governance sustainability is the best in "semi-market" (Mainly for Selfsufficiency) and "cooperative" (Cooperatives) sectors being much higher than the industry average. Thus these two sectors of farming activity enhance to the greatest extent Governance sustainability of Bulgarian agriculture. At the same time, Small Size farming holdings are with marginal to satisfactorily Governance sustainability. What is more, Governance sustainability in large enterprises and business sector (Agro-companies and farms with a size Large for the Industry) is satisfactory. Therefore, the latter types of farming organization reduce to the greatest degree the overall Governance sustainability of country's agriculture.

Principles of Governance sustainability are realized differently in the major subsectors of Bulgarian agriculture deviating from the national (sectoral) in one or another direction (Figure 6). Principle Good Legislative System is best realized in Vegetables, Flowers, and Mushrooms production, and Mix-livestock operations, and worst in Field Crops and Grazing Livestock sub-sectors. Principle of Democratic management is best applied in Mix livestock production, while it is satisfactorily implemented in Mix Crops and Mix Crop-livestock sub-sectors. Principle Working Agrarian Administration is effectively applied for Grazing Livestock and Mix Crop- 
livestock sub-sectors, while agrarian administration does not "work" well in Field Crops sector. Principle Working Market Environment is highest in Mix Livestock and Mix Crop-livestock sectors. Simultaneously, market mechanisms are not working well for Field Crops producers. Good Private practices are best implemented in subsector Mix Livestock while in other subsectors they are applied only satisfactorily.

Figure 6. Application of Principles of Governance Sustainability in Major Subsectors of Bulgarian Agriculture (national average in red)

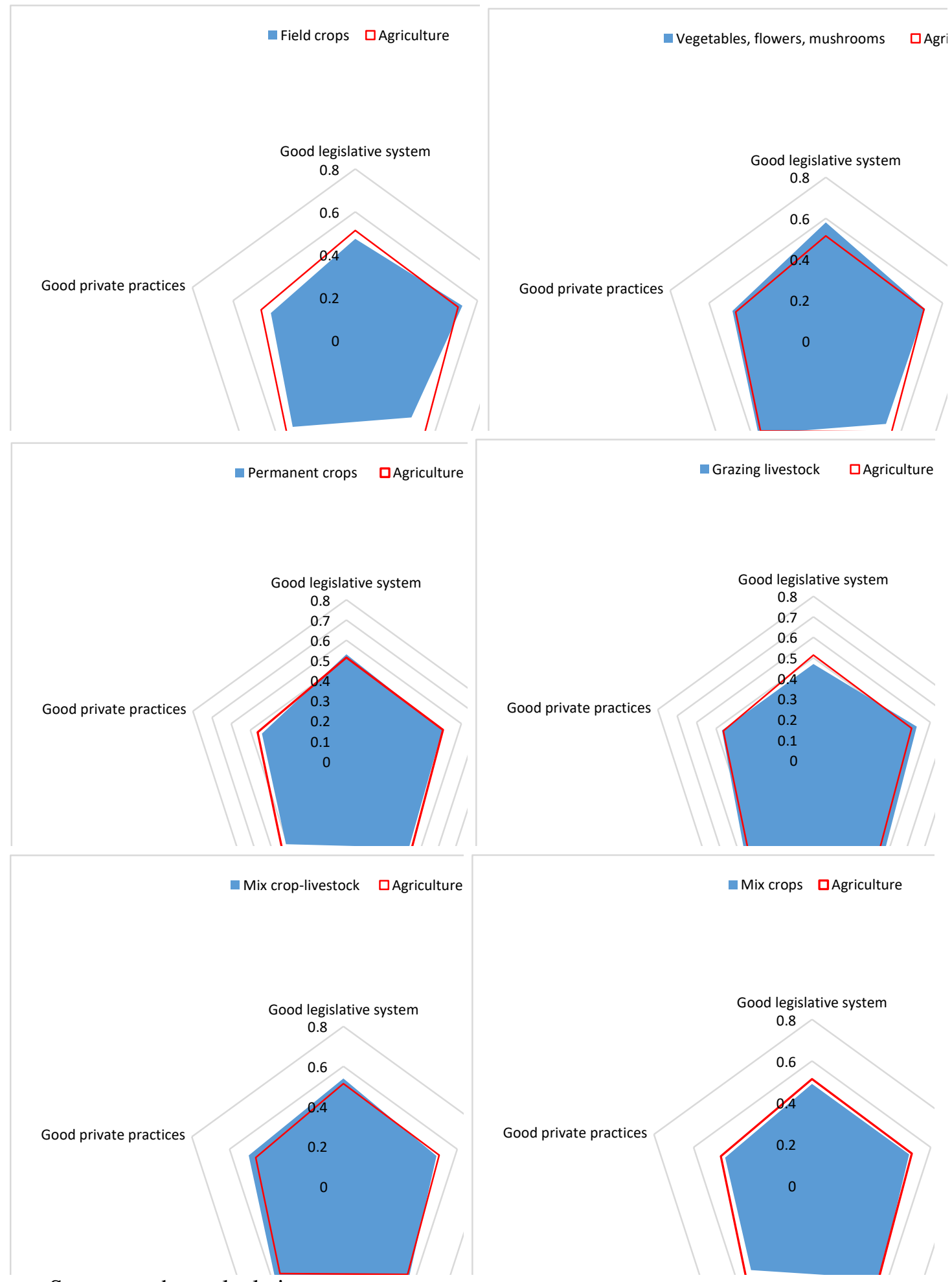

Source: author calculation 
There is a significant variation from the national average in the level of diverse aspects of governance efficiency among administrative (and agricultural) regions of the country. While sustainability principle Good Legislative System dominates in North-West region and North-Central region, in South-Central region and South-West region it is applied satisfactorily. Principle of Democratic Management is best realized in North-East region and South-West region, and insufficiently in SouthCentral region and North-West region. Principle Working Agrarian Administration is effectively applied in North-East region and North-East region, and only satisfactorily in South-Central region. Principle Working Market Environment is highly regarded in North-East region while in South-Central region and South-East region it is inferior implemented. Good private practices are best carried out in North-Central region and North-East region while in the south regions of the country they are enforced satisfactorily.

System of governance of Bulgarian agriculture does not impact equally farming organizations of different type since diverse principles of Governance sustainability are applied ("work") quite unlikely. Principles Good Legislative System, Democratic Management, and Good Private Practices the most favorably affect Cooperatives and Mainly Subsistence farms. Principle Working Agrarian Administration is most effectively implemented in regards to Mainly Subsistence holdings, Physical Persons and Middle Size farms. Principle Working Market Environment is more favorable for Middle Size and Small Size farms. On the other hand, at satisfactory level is the application of Governance sustainability principle Good Legislative System for Agrofirms and Small Size farms, principle of Democratic Management for Big Size farming enterprises, principle Working Agrarian Administration for Big Size farms and Cooperatives, principle Working Market Environment for Big Size farms and Agro-firms, and principle Good Private Practices for Agro-firms, Middle Size farms, Physical Persons, and Small Size holdings.

\section{Conclusion}

This first of a kind study tried to evaluate the level and significance of Governance sustainability of Bulgarian agriculture. It demonstrated that it is possible and important to assess the "missing" Governance Pillar of agrarian sustainability. Comprehensive assessment of Governance sustainability of the country's agriculture indicates that it is at a good but close to the inferior level. There is a considerable variation in the level of Governance sustainability and application of the principles for good governance in agro-systems of a different type - diverse subsectors, agroecosystems, administrative regions, and types of farming organizations. Detailed analysis of the sustainability level for individual principles and indicators give a new insight into "critical" factors enhancing or deterring Governance sustainability as a whole and in a particular agro-system. Sustainability assessments of this type not only precise (reassess) sustainability evaluations but also (could) assist improvement of sustainability governance - amelioration of public policies and (farm, agri-business, producer organization, etc.) management strategy formation at national, regional, sectoral, ecosystem, and farm levels.

There are no similar studies in Bulgarian agriculture and internationally, and the results of this research cannot be compared with other assessments. Elaboration of a 
comprehensive framework for assessing Governance and Integral sustainability is a "work in progress", and presented and other similar frameworks have to be further discussed, tested, improved, and adapted to the specific conditions of agricultural systems and the needs of decision-makers. Accuracy also has to be improved through the inclusion of appropriate indicators, improvement of precision of information, increasing representation of surveyed farms, and experimenting with diverse types of agro-systems. Particular attention is to be given to the incorporation of indicators better reflecting the Sustainability Development Goals of the UN and the new EU Green Deal. Since much of the needed information for measuring Governance and Overall sustainability is not readily available, it has to be systematically collected by FADN, professional organizations, research institutes, regional and central authorities, etc.

\section{References}

Altinay H. (2012): Global Governance Audit, Global Economy \& Development, Working Paper 49, Brookings Institution, Washington, DC.

ASA (2019): More than Green, ASA, http://www.morethangreen.es/en/ideology/four-sustainabilities-cultural-economicsocial-environmental-sustainability/\#sthash.IjtNJlyH.dpbs

Bachev H. (2005): Assessment of Sustainability of Bulgarian Farms, proceedings, XIth Congress of the European Association of Agricultural Economists, Copenhagen.

Bachev H. (2009): Understanding Efficiency of Agrarian Organization, Journal Annals of the University of Petrosani - Economics, Volume 9, Issue 1, 27-42.

Bachev H. (2010): Governance of Agrarian Sustainability, New York: Nova Science Publishers.

Bachev H. (2013): Risk management in the agri-food sector, Contemporary Economics, Volume 7, Issue 1, 45-62.

Bachev H. (2013): New approach for assessing and improvement of environmental management and strategies in agri-business, Global Journal of Management And Business Research, 6.

Bachev H (2016): A Framework for Assessing Sustainability of Farming Enterprises, Journal of Applied Economic Sciences, Spring Issue, Vol XI, 1(39), 2443.

Bachev H. (2016): Defining and Assessing the Governance of Agrarian Sustainability, Journal of Advanced Research in Law and Economics, Volume VII, Issue 4(18), 797-816.

Bashev H. (2016): Defining and assessment of sustainability of farms, Economic Studies Journal, 3, 158-188.

Bachev H. (2016): Unpacking Sustainability of Farming Organizations, International Journal of Economics and Management Sciences, Volume 5, Issue 3, 113.

Bachev H. (2017): Socio-economic and environmental sustainability of Bulgarian farms. Agricultural and Resource Economics: International Scientific EJournal, vol. 3 (2), 5-21.

Bachev H. (2017): Sustainability Level of Bulgarian Farms, Bulgarian Journal of Agricultural Science, 23 (1), 1-13.

Bachev H. (2017): Sustainability of Bulgarian Farming Enterprises during EU CAP Implementation, Journal of Applied Economic Sciences, 2(48), 422-451. 
Bachev H. (2018): The Sustainability of Farming Enterprises in Bulgaria, Cambridge Scholars Publishing.

Bachev H. (2018): Institutional Environment and Climate Change Impacts on Sustainability of Bulgarian Agriculture, Bulgarian Journal of Agricultural Science, 24 (4), 523-536.

Bachev H. (2020): About the Governance Pillar of Agrarian Sustainability, Журнал Economic Consultant, 4.

Bachev H. (2020): Measuring the New Governance Pillar of Agrarian Sustainability at Farm, Sectoral and National Level in Bulgaria, Asian Business Research Journal, Vol. 4, No. 2.

Bachev H. (2020): Governance Sustainability of Agriculture at National, Territorial and Farm Levels in Bulgaria, Social Sciences Review Quarterly, Vol. 1, No. 1, 1-13.

Bachev H. (2020): Evaluating New Governance Pillar of Sustainability of Bulgarian Agriculture, Journal of Purchasing, Logistics and Supply Chain Management System, Volume-1.

Bachev H. (2020): Measuring Critical Governance Sustainability at various levels -The Case of Bulgarian Agriculture, IUP Journal of Supply Chain Management, 4.

Bachev H. (2020):Territorial Dimensions Of Governance Sustainability - The Case Of Bulgarian Agriculture, Journal:Sumerianz Journal of Agriculture and Veterinary, Volume 3 Issue 11, 155-166.

Bachev H. (2020): State and Evolution of Public and Private Research and Development in Bulgarian Agriculture, International Journal of Sustainable Development \& World Policy 9 (1), 10-25.

Bachev H. (2021): Governance Sustainability of Bulgarian Agriculture at Ecosystem Level, South Asian Research Journal of Agriculture and Fisheries, Volume-3 | Issue-1 | Jan-Feb -2021, 1-9.

Bachev H. (2021): THE "FOURTH" PILLAR OF SUSTAINABILITY OF BULGARIAN AGRICULTURE, in Hristo PARVANOV, Georgi Chankov (editors) 2020 "China and Central \& Eastern Europe" International Scientific Forum, Proceedings of the scientific conference, November 18, Shanghai - Sofia, 58-68.

Bachev H., B. Ivanov, D. Toteva, E. Sokolova (2016): Agrarian Sustainability and its Governance - Understanding, Evaluation, Improvement, Journal of Environmental Management and Tourism, Vol. 7, issue 4 (16), 639-663.

Bachev H., B. Ivanov, D.Toteva and E.Sokolova (2017): Agrarian sustainability in Bulgaria - economic, social and ecological aspects, Bulgarian Journal of Agricultural Science, 23 (4), 519-525.

Bachev H. and D.Terziev (2017): Environmental Sustainability of Agricultural Farms in Bulgaria, Journal of Environmental Management and Tourism, Vol 8 No 5 (2017): JEMT Volume VIII Issue 5(21) Fall 2017, 968-994.

Bachev, H., Terziev, D. (2018): A Study on Institutional, Market and Natural Environment Impact on Agrarian Sustainability in Bulgaria, Journal of Environmental Management and Tourism, Vol. IX, Issue 3 (27), 452-478.

Bachev, H., Terziev, D. (2019): Sustainability of Agricultural Industries in Bulgaria, Journal of Applied Economic Sciences, Volume XIV, Issue 1(63) Spring 2019, 118-129.

Bachev H., N.Koteva, K.Kaneva, P.Yovchevska, D.Mitova, B.Ivanov, S.Alexandrova, D.Toteva, A.Sarov, E.Sokolova (2018): A System for Assessing Sustainability of Bulgarian Agriculture, IAE, Sofia. 
Bachev H., N.Koteva, D.Mitova, B.Ivanov, M. Anastasova-Chopeva, D.Toteva, A.Sarov, E.Sokolova, K.Todorova, A Mitov (2019): Assessment of Sustainability of Bulgarian Aghriculture, IAE, Sofia.

Bachev H., B. Ivanov, A. Sarov (2020): Unpacking Governance Sustainability of Bulgarian Agriculture, Economic Studies, 6. 106-137.

Bachev H., B.Ivanov, A. Sarov (2020): Why and How to Assess the "Governance" Aspect of Agrarian Sustainability - The Case of Bulgaria, Agricultural Research Updates. Volume 30. Editors Prathamesh Gorawala and Srushti Mandhatri, New York, Nova Science Publisher.

Baeker G. (2014): Fourth Pillar of Sustainability, Economicdevelopment.org, February 18, 2014, http://economicdevelopment.org/2014/02/fourth-pillar-ofsustainability-2/

Bhuta N. and G.Umbach (2014): Global Governance by Indicators, European University Institute, http://globalgovernanceprogramme.eui.eu/global-governance-byindicators/

Bell S. and Morse S. (2008): Sustainability Indicators: Measuring the Immeasurable? Earthscan: London.

Brklacich M., Bryant C. and B.Smith (1991): Review and appraisal of concept of sustainable food production systems, Environmental Management, 15(1): 1-14.

Bosselmann K., R. Engel, and P. Taylor (2008): Governance for Sustainability Issues, Challenges, Successes, IUCN, Gland, Switzerland.

Burford G., E. Hoover, I. Velasco, S. Janoušková, A. Jimenez, G. Piggot, D. Podger and M. Harder (2013): Bringing the "Missing Pillar" into Sustainable Development Goals: Towards Intersubjective Values-Based Indicators, Sustainability 2013, 5, 3035-3059; doi:10.3390/su5073035

City of Brooks (2019): Municipal Sustainability Plan, Five Pillars, City of Brooks https://www.brooks.ca/211/Sustainability

Cruz F., Y. Mena, V. Rodríguez-Estévez (2018): Methodologies for Assessing Sustainability in Farming Systems, in S. Gokten and P. Okan Gokten Sustainability Assessment and Reporting,, IntechOpen, DOI: 10.5772/intechopen.79220.

CoastalWiki (2019): Measuring sustainability: The self-assessment of sustainability using indicators and a means of scoring them, Coastal Wiki, http://www.coastalwiki.org/wiki/Measuring_sustainability

EC (2001): A Framework for Indicators for the Economic and Social Dimensions of Sustainable Agriculture and Rural Development, European Commission.

Edwards C.,R.Lal, P.Madden, R.Miller and G.House (editors) (1990): Sustainable Agricultural Systems, Soil and Water Conservation Society, Iowa.

EU (2019): European Governance, EU, https://eurlex.europa.eu/summary/glossary/governance.html

FAO (2013): SAFA. Sustainability Assessment of Food and Agriculture systems indicators, FAO.

Fraser E., Dougill A., Mabee W., Reed M., McAlpine P. (2006): Bottom up and top down: Analysis of participatory processes for sustainability indicator identification as a pathway to community empowerment and sustainable environmental management. Journal Environment Management, 78, 114-127.

IFAD (1999): Good Governance: An Overview, IFAD, Executive Board Sixty-Seventh Session, Rome, 8-9 September 1999, EB 99/67/INF.4.

Ganev G. M. Popova, F. Bönke (2018): Bulgaria Report, Sustainable Governance Indicators 2018, SGI 2018, 2, Bertelsmann Stiftung. 
Georgiev, M. (2013): Impact of the Administration Structure and Transaction Costs on the Agricultural Land Market, Trakia Journal of Sciences, 11(11), 527-534.

Gibson R. (2006): Beyond the Pillars: Sustaibaility Assessment as a Framework for Effective Integration of Social, Economic and Ecological Considerations in Significant Decision-Making, Journal of Environmental Assessment Policy and Management, Vol. 8, No. 3, 259-280.

Hansen J. (1996): Is Agricultural Sustainability a Useful Concept, Agricultural Systems 50: 117-143.

Hayati D. Z. Ranjbar, and E. Karami (2010): Measuring Agricultural Sustainability, in E. Lichtfouse (ed.), Biodiversity, Biofuels, Agroforestry and Conservation Agriculture, Sustainable Agriculture Reviews 5, Springer Science, 73 100.

Kayizari C. (2018): Good Governance as a pillar of Sustainable Development in Africa, PPP https://www.aydin.edu.tr/trtr/arastirma/arastirmamerkezleri/afrikam/Documents/Oturum\%203\%20-\%20GoodGovernance-as-a-pillar-for-sustainable-Development-in-Africa_CaesarKayizari.pdf

Marinov P. (2019), Index of localization of agricultural holdings and employees in the rural areas of the South Central Region for Bulgaria, Volume 25, Issue 3, Bulgarian Journal of Agricultural, pp. 464-467.

Mirovitskaya N. and W.Ascher (editors) (2001): Guide to Sustainable Development and Environmental Policy, Duke University Press, London.

Kamalia F., J.Borges, M.Meuwissen, I. Boer, A.Lansink (2017): Sustainability assessment of agricultural systems: The validity of expert opinion and robustness of a multi-criteria analysis, Agricultural Systems, Vol. 157, 118-128.

Lewandowski, I., Härdtlein M., Kaltschmitt M. (1999): Sustainable crop production: definition and methodological approach for assessing and implementing sustainability. Crop science 39:184-193.

Lopez-Ridauira S., O. Masera, and M. Astier (2002): Evaluating the sustainability of complex socio-environmental systems. The MESMIS framework. Ecological indicators 2: 135-148.

Lowrance R., P, Hendrix, and E. Odum (2015): A hierarchical approach to sustainable agriculture, American Journal of Alternative Agriculture.

Monkelbaan J. (2017): Achieving the Sustainable Development Goals: Theoretical insights and case studies for making sustainability governance more integrative, V. R. F. Series, No. 499, INSTITUTE OF DEVELOPING ECONOMIES, JAPAN EXTERNAL TRADE ORGANIZATION.

Monkelbaan J. (2018): Governance for the Sustainable Development Goals Exploring an Integrative Framework of Theories, Tools, and Competencies, Springer.

North D. (1990): Institutions, Institutional Change and Economic Performance, Cambridge: Cambridge University Press.

Nurse K. (2006): Culture as the Fourth Pillar of Sustainable Development; Commonwealth Secretariat: London, UK.

OECD (2001): Environmental indicators for agriculture. Volume 3: Methods and Results. OECD, Paris.

Raman, S. (2006). Agricultural Sustainability. Principles, Processes and Prospect., New York: The Haworth Press Inc.

RMIT University (2017): The four pillars of sustainability. RMIT University https://www.futurelearn.com/courses/sustainable-business/1/steps/157438

Sarov A. (2019): Assessment of the governance sustainability of farms located in mountain areas with natural constraints, BJAEM, 2, 51-59. 
Simberova I., A. Kocmanova, P. Nemecek (2012): Corporate Governance Performance Measurement - Key Performance Indicators, Economics and Management, Vol 17, No 4, http://158.129.0.15/index.php/Ekv/article/view/3033/0

Scobie S. and O. Young (2018): Integrating Governance into the Sustainable Development Goals, Post2015, UNU-IAS, Policy Brief 3.

Sauvenier X., J. Valekx, N. Van Cauwenbergh, E. Wauters, H.Bachev. K.Biala, C. Bielders, V. Brouckaert, V. Garcia-Cidad, S. Goyens, M.Hermy, E. Mathijs, B.Muys, M.Vanclooster. and A.Peeters (2005): Framework for Assessing Sustainability Levels in Belgium Agricultural Systems - SAFE, Belgium Science Policy, Brussels.

Singh R., H.Murty, S. Gupta, A.Dikshit (2009): An overview of sustainability assessment methodologies, Ecological indicators, 9, 189-212.

Spangenberg J., Pfahl S. Deller K. (2002): Towards indicators for institutional sustainability: Lessons from an analysis of Agenda 21. Ecological Indicators, 2, 6177.

Terziev D., D. Radeva, \& Y. Kazakova (2018): A new look on agricultural sustainability and food safety: Economic viability, in H. BACHEV, S. CHE, S. YANCHEVA (Editors) Agrarian and Rural Revitalisation Issues in China and Bulgaria, KSP Books, 231-242.

UCLG (2014): Culture: Fourth Pillar of Sustainable Development, United Cities and Local Governments, Barcelona.

VanLoon G., S. Patil, and L.Hugar (2005): Agricultural Sustainability: Strategies for Assessment. London: SAGE Publications.

UN (2015): The Sustainable Development Goals (SDGs), United Nation.

Williamson, O. (1996). The Mechanisms of Governance. New York: Oxford University Press. 